\title{
ANALISIS AKTIVITAS BELAJAR SISWA DALAM PEMBELAJARAN GEOGRAFI DI KELAS X IIS 1 SMA NEGERI 4 PADANG
}

\author{
Oleh: \\ Nadia Turrahima *,Yurni Suasti**, Nofrion** \\ *Mahasiswa S1 Prodi Pendidikan Geografi**Dosen Jurusan Geografi UNP \\ Email: turrahima_nadia@yahoo.com
}

\begin{abstract}
ABSTRAK
Penelitian ini bertujuan untuk mendeskripsikan data tentang aktivitas belajar siswa dalam pembelajaran geografi dikelas X IIS 1 SMA Negeri 4 Padang.Penelitian ini adalah penelitian deskriptif kuantitatif. Populasi dalam penelitian ini adalah seluruh siswa kelas X SMA Negeri 4 Padang, pengambilan sampel dilakukan dengan teknik purposive samplingyaitu kelas yang memiliki rata-rata nilai terendah. sehingga yang menjadi sampel yaitu kelas X IIS 1 dengan jumlahsiswa 32 orang. Data dikumpulkan menggunakan lembar observasi dandianalisis dengan menggunakan analisis deskriptif.Penelitian ini menemukan : (1) Tingkat aktivitas siswa dalam mengamati pembelajaran berada pada tingkat sedang. (2) Tingkat aktivitas siswa dalam menulis/mencatat pembelajaran berada pada tingkat sedang. (3) Tingkat aktivitas siswa dalam mengumpulkan informasi pembelajaran berada pada tingkat sedang. (4) Tingkat aktivitas siswa dalam berfikir/memecahkan masalah berada pada tingkat sedang. (5) Tingkat aktivitas siswa dalam berdialog pada saat pembelajaran berada pada tingkat sedang. (6) Tingkat aktivitas siswa dalam berkolaborasi pada saat pembelajaran berada pada tingkat sedang

Keyword: Aktivitas Belajar Siswa, Pembelajaran Geografi
\end{abstract}

\section{PENDAHULUAN}

Pendidikan merupakan salah satu faktor terpenting dalam meningkatkan kualitas sumber daya manusia dan taraf kehidupan bangsa. Dalam Pasal 1 UndangUndang Nomor 20 Tahun 2003 tentang Sistem Pendidikan Nasional, disebutkan bahwa pendidikan adalah usaha sadar dan terencana untuk mewujudkan suasana belajar dan proses pembelajaran agar peserta didik secara aktif mampu mengembangkan potensi dirinya untuk memiliki kekuatan spiritual, pengendalian diri, kepribadian, kecerdasan, akhlak mulia, serta keterampilan yang diperlukan dirinya, masyarakat,bangsa dan negara.

Kegiatan pembelajaran yang dilakukan tidak akan berjalan dengan optimal jika tidak memiliki tingkKegiatan pembelajaran yang dilakukan tidak akan berjalan dengan optimal jika tidak memiliki tingkat aktivitas belajar yang tinggi oleh siswa. Karena siswa yang aktif merupakan pemicu dan pendorong untuk siswa berhasil dalam pembelajaran. Konsep idealnya dalam proses pembelajaran keterlibatan siswa dalam pembelajaran agar terciptanya siswa aktif diartikan sebagai partisipan dalam proses belajar mengajar, keaktifan siswa dapat didorong oleh peran guru. Guru berupaya untuk memberi kesempatan siswa untuk aktif, baik aktif mencari, memproses dan mengelola perolehan dalam pembelajaran.

Ada beberapa masalah yang penulis temui di lapangan bahwa masih terdapat siswa yang bermasalah dalam 
belajar geografi atau proses belajar geografi. Hal tersebut dapat dilihat dari tingkat kehadiran mereka, beberapa siswa terlihat tidak mengikuti pelajaran. Selama proses belajar mengajar berlansung, khusunya mata pelajaran geografi yang penulis amati lansung di lapangan ditemukan bahwa masih rendahnya aktivitas belajar siswa dalam mengikuti pembelajaran geografi di SMA Negeri 4 Padang, hal tersebut dapat dilihat pada saat pelaksanaan proses belajar mengajar berlangsung dimana masih banyak siswa yang malas dalam melakukan aktivitas belajar.

SMA Negeri 4 Padang adalah sekolah yang berada di daerah Kecamatan Lubuk Begalung, Padang. Pada Tahun ajaran 2013-2014 kementerian pendidikan dan kebudayaan menetapkan di Indonesia menggunakan kurikulum 2013, termasuk SMA Negeri 4 Padang yang sudah menggunakan kurikulum 2013 sejak tahun 2013-2014 hingga sekarang masih menerapkan kurikulum 2013, dimana pembelajarannya menggunakan pembelajaran tematik integratif dengan pendekatan saintifik. Pelaksanaan kurikulum 2013 di SMA Negeri 4 Padang sudah melakukan aturan atau tata cara peaksanaan kurikulum 2013 dengan baik. Terbukti dengan adanya kesiapan guru dan peserta didik yang bekerja sama dengan baik. Meskipun SMA Negeri 4 padang telah menerapkan kurikulum 2013 namun masih banyak masalah yang dialami oleh guru dalam mengimplementasikan kurikulum 2013 khususnya di kelas X IIS 1, dalam menerapkan pendekatan saintifik dalam proses pembelajaran dan terkadang guru mata pelajaran masih menggunakan pendekatan konvensional, dalam pembelajaran dimana siswa masih sebagai objek pembelajaran, guru mata pelajaran geografi sebagai inti pembelajaran. Dan pembelajaran belum berorientasi pada siswa.

Di sinilah letak pentingnya peranan aktivitas belajar dalam pembelajaran di kelas. Pada dasarnya siswa sebagai makhluk individu memiliki perbedaan antarsiswa yang satu dengan yang lain. Perbedaan tersebut meliputi perbedaan karakter,sikap dan tingkah laku, minat dan bakat serta masih banyak perbedaanperbedaanlainnya. Dengan perbedaan dari masing-masing individu tersebut tentunya banyaksekali masalah-masalah yang timbul diantara para siswa. perbedaan kepribadian (Sardiman,2007: 12 4).

Berdasarkan uraian di atas, penulis tertarik melakukan penelitian berjudul "Analisis Aktivitas Belajar Siswa Dalam Pembelajaran Geografi di Kelas X IIS 1 SMA Negeri 4 Padang"

\section{KAJIAN PUSTAKA}

Kartini Kartono (1993:8) Aktivitas merupakan istilah umum yang dikaitkan dengan keadaan yang bergerak, eksplorasi dan berbagai respon lainnya terhadap ransangan sekitar. Abu Ahmadi dan Widodo Supriyo (2004:27) belajar diartikan sebagai suatu proses usaha yang harus dilakukan seseorang untuk memperoleh perubahan tingkah laku yang baru secara keseluruhan sebagai hasil pengalamannya sendiri dalam interaksi dengan lingkungannya. Djamarah (2008:38) aktivitas belajar dapat diartikan sebagai kemauan berbuat dan bekerja yang dilakukan untuk menghasilkan perubahan pengetahuan, nilai-nilai sikap, dan keterampilan pada siswa sebagai latihan yang dilaksanakan secara sengaja. 
Ahmadi (2004: 132) Sekolah adalah salah satu pusat kegiatan belajar. Dengan Demikian, di sekolah merupakan arena untuk mengembangkan aktivitas. Banyak jenis aktivitas yang dapat dilakukan oleh siswa di sekolah. Aktivitas siswa tidak cukup hanya mendengarkan dan mencatat seperti yang lazim terdapat di sekolahsekolah tradisional.

Tujuan pembelajaran geografi terbagi menjadi 3 bagian yaitu :

1. Pengetahuan

a. Mengembangkan konsep dasar dan memiliki daya analisisyang berwawasan keruangan, sehingga mampu berorientasi terhadap tempat tinggalnya didalam geosfer. Memahami arah, lokasi, jarak,bentuk, dan mampu mengaplikasikannya dalam kehidupan sehari-hari.

b. Mengembangkan pengetahuan sumber daya alam yang ada dilingkungan sekitarnya, terbentuknya, ketersediaannya, pengelolaan, dan pemanfaatannya. Sehingga sumber daya alam yang tersedia dapat bermanfaat dan terlestarikan.

2. Keterampilan

Memiliki keterampilan dalam mengamati lingkungan sekitar (fisik maupun sosial) dan mencatatnya sebagai data dan informasi dan selajutnya di analisis untuk menghasilkan suatu kesimpulan yang dapat digunakan untuk mengembangkan wilayah tersebut.

3. Sikap

a. Memahami dan memiliki ke pekaan terhadap permasalahan yang terjadi di lingkungan sekitar.

b. Memiliki sikap melindungi terhadap kerusakan alam sekitar dan bertanggung jawab terhadap kualitas lingkungan sekitar.

\section{METODE PENELITIAN}

Penelitian ini merupakan penelitian deskriptif kuantitatif.. Populasi dari penelitian ini adalah siswa kelas X SMA Negeri 4 Padang, dengan teknik pengambilan sampel adalah purposive sampling, yaitu kelas yang memiliki nilai terendah yaitu kelas X IIS 1 SMA Negeri 4 Padang. Data dikumpulkan melalui observasi dan dianalisis dengan teknik analisis deskriptif.

\section{HASIL DAN PEMBAHASAN}

Berdasarkan enam indikator aktivitas yang diamati dalam kegiatan pembelajaran, diperoleh hasil aktivitas belajar yang bervariasi sebagai berikut:

\begin{tabular}{|c|c|c|c|}
\hline \multirow[t]{2}{*}{ No } & \multirow[t]{2}{*}{ Indikator } & \multicolumn{2}{|c|}{ Tingkat aktivitas } \\
\hline & & $\%$ & KET \\
\hline 1 & Mengamati & 66.32 & Sedang \\
\hline 2 & $\begin{array}{l}\text { Menulis/Me } \\
\text { ncatat }\end{array}$ & 65.28 & Sedang \\
\hline 3 & $\begin{array}{l}\text { Mengumpul } \\
\text { kan } \\
\text { Informasi }\end{array}$ & 56.04 & Sedang \\
\hline 4 & $\begin{array}{l}\text { Berfikir/me } \\
\text { mecahkan } \\
\text { masalah }\end{array}$ & 57.29 & Sedang \\
\hline 5 & Dialog & 60.41 & Sedang \\
\hline 6 & Kolaborasi & 56.25 & Sedang \\
\hline & Rata-rata & 60.26 & Sedang \\
\hline
\end{tabular}

Sumber: pengolahan data primer 2016

Pada tabel di atas dapat dilihat bahwa aktivitas belajar siswa dalam pembelajaran geografi di kelas X IIS 1 SMA Negeri 4 Padang memiliki tingkat aktivitas belajar yang Sedang dalam pembelajaran Geografi dengan rata-rata tingkat aktivitas dari enam indikator aktivitas $60.26 \%$. Dimana siswa memiliki aktivitas Sedang yaitu $66.32 \%$ dalam mengamati pada saat pembelajaran geografi, memiliki aktivitas sedang yaitu 
$65.28 \%$ dalam Menulis/mencatat pada saat pembelajaran geografi, memiliki aktivitas sedang yaitu $56.04 \%$ dalam mengumpulkan informasi terkait dengan pembelajaran geografi, memiliki aktivitas sedang yaitu: $57.29 \%$ dalam berfikir/memecahkan masalah pada saat pembelajaran geografi, memiliki aktivitas sedang yaitu $60.41 \%$ dalam berdialog pada saat pembelajaran geografi dan juga memiliki aktivitas sedang yaitu $56.25 \%$ dalam bekolaborasi pada saat pembelajaran geografi.

Hal ini sesuai dengan yang diungkapkan Kartini Kartono (1993:8) Aktivitas merupakan istilah umum yang dikaitkan dengan keadaan yang bergerak, eksplorasi dan berbagai respon lainnya terhadap ransangan sekitar. Abu Ahmadi dan Widodo Supriyo (2004) belajar diartikan sebagai suatu proses usaha yang harus dilakukan seseorang untuk memperoleh perubahan tingkah laku yang baru secara keseluruhan sebagai hasil

\section{DAFTAR RUJUKAN}

UUD NO 20 Tahun 2003

Abu Ahmadi \& Supriyono Widodo. (2004). Psikologi Belajar. Jakarta: PT Rineka. Cipta Djamarah, Syaiful Bahri.2008. Psikologis Belajar. Jakarta: Rineka Cipta.

Darmadi, Hamid. 2014. Metode Penelitian Pendidikan dan Sosial. Bandung : Alfabeta

Daryanto. 2014. Pendekatan Pembelajaran Sainstifik Kurikulum 2013. Yogyakarta: Penerbit Gava Media

Kartono, Kartini. 1993. Kamus Lengkap Psikologi. Jakarta: PT. Raja Grafindo Persada. Sugiono.2012. Memahami Metode Penelitian. Bandung: ALFABETA 